\title{
The Statistical Analysis of Quasi-Experiments
}



Christopher H. Achen

\section{THE STATISTICAL ANALYSIS OF QUASI-EXPERIMENTS}

UNIVERSITY

OF

CALIFORNIA PRESS

Berkeley

Los Angeles

London 
University of California Press

Berkeley and Los Angeles, California

University of California Press, Ltd.

London, England

(C) 1986 by

The Regents of the University of California

Library of Congress Cataloging-in-Publication Data

Achen, Christopher $\mathrm{H}$.

The statistical analysis of quasi-experiments.

Includes index.

1. Social sciences-Statistical methods.

2. Experimental design. I. Title.

HA29.A32 $1986 \quad 300^{\prime} .15195 \quad 85-14150$

ISBN 0-520-04723-0 (alk. paper)

ISBN 0-520-04724-9 (pbk. : alk. paper)

Printed in the United States of America

123456789 
For Tena 
